\title{
DETERMINANTS OF TURKISH STOCK RETURNS UNDER THE IMPACT OF ECONOMIC POLICY UNCERTAINTY
}

\author{
Havva Nesrin TIRYAKi ${ }^{1} \quad$ Ahmet TIRYAKi ${ }^{2}$
}

\begin{abstract}
This paper aims to investigate the short-run and long-run macroeconomic determinants of the Turkish stock returns under the impact of the "domestic and global economic policy uncertainty" by using the ARDL method and the monthly data for the period of 1991:M1 to 2017:M12. The set of macroeconomic variables utilized in the study are the stock market price indexes of Turkey's BIST100 index (BIST) and the BIST industrial index (IND), industrial production index (IPI), real effective exchange rate (RER), consumer price index (CPI), interest rate (R), Geopolitical risk index for Turkey (GPR) and the Economic Policy Uncertainty index of the United States of America (EPU). The ARDL estimation results reveal that in the short-run the BIST stock returns are positively affected from the changes in IPI, RER and CPI. The effects of the changes in Turkish interest rate (R), EPU and the dummy representing the impact of the 2008 Global Financial Crisis on the stock returns are negative. The long-run determinants of the BIST stock returns are the changes in IPI, RER, and CPI and the EPU. The effect of the changes in the EPU on the stock returns is negative and the effect of the other variables are positive.
\end{abstract}

Keywords: Economic Policy Uncertainty, ARDL, Stock Returns, Economic Activity, BIST.

JEL codes: D81, C22, D89, E44, F3, F47

\section{EKONOMIK POLITIKA BELIRSIZLiĞi ALTINDA BORSA ISTANBUL HISSE SENEDi GETIRILERININ MAKROEKONOMIK BELIRLEYICILERi}

\section{Öz}

Bu makalenin amacı yerel ve global ekonomik politika belirsizliği altında Türkiye'de hisse senedi getirilerinin belirleyicilerinin hangi makroekonomik değişkenler olduğunu ARDL metodu ve 1991-2017 yılları arası dönemde aylık veriler kullanarak belirlemektir. Çalışmada; bağımlı değişken olarak Borsa İstanbul'un BIST100 (BIST) ve Endüstri endeksleri (IND) ve bağımsız değişkenler olarak da Türkiye imalat sanayi endeksi (IPI), reel döviz kuru (RER), tüketici fiyat endeksi (CPI), faiz oranı (R), Türkiye'nin jeopolitik risk endeksi (GPR) ve ABD'nin ekonomik politika belirsizliği (EPU) verilerinden yararlanılmıştır. ARDL tahmin sonuçları, kısa dönemde BIST hisse senedi getirilerinin belirleyicilerinin pozitif olarak IPI, RER ve CPI; negatif olarak da R, EPU ve 2008 global finansal krizini temsil eden "kukla değişkeni" olduğunu ortaya koymaktadır. Uzun dönemde ise IPI, RER ve CPI'daki değişmeler pozitif, EPU'daki değişmeler ise hisse senedi getirilerine negatif etki etmektedir.

Anahtar Kelimeler: Ekonomik Politika Belirsizliği, ARDL, Hisse Getirileri, Ekonomik Aktivite, BIST. JEL Kodları: D81, C22, D89, E44, F3, F47

\footnotetext{
${ }^{1}$ Assistant Professor at Bilecik Şeyh Edebali University. Address: Bilecik Şeyh Edebali University, Faculty of Economic and Administrative Sciences, Department of Economics, B Blok, No: 221, 11100 Gülümbe-Bilecik, Phone: 090(228)2141216, email: nesrin.ozkan@bilecik.edu.tr ORCID 0000-0002-0083-0827

${ }^{2}$ Corresponding Author: Assoc. Prof. at Anadolu University. Address: Anadolu University, AÖF, Room No: 602, Yunus Emre Kampusü, 26470, Eskişehir/Turkey, Phone: 905303291927, e-mail: ahmettiryaki@anadolu.edu.tr ORCID: 0000-0002-95277736
} 


\section{Introduction}

The stock prices reflect the investors' expectations about the future firm profits. According to the Fama's (1970) efficient market hypothesis, asset prices reflect all available information and only react to the arrival of new information which affects economic agents' expectations about future economic activity. Changes in macroeconomic variables, especially those that are related to aggregate macroeconomic activity and news/information about the risk and economic policy uncertainty have a significant impact on stock market performance as the literature suggest. Beside the changes in macroeconomic variables, the developments in domestic and global risk and uncertainty about economic policy also affects the stock market returns. Increases in the geopolitical risk of a country and economic policy uncertainty are expected to affect the economic activity, investment and hence the stock market returns negatively.

There are various studies already investigated the effects of the changes of the different macroeconomic variables on stock returns both theoretically and empirically, but effects of these variables on the returns under the assumption of risk and economic policy uncertainty is new. Thus, this paper aims to investigate the short and long-run causal relationship between key domestic and international macroeconomic variables, including industrial production index (IPI), real effective exchange rate (RER), consumer price index (CPI), interest rate (R), Geopolitical risk index for Turkey (GPR) and the Economic Policy Uncertainty index of the United States of America (EPU) and the stock market prices in Turkey, represented by the stock market price indexes of Turkey's BIST100 index (BIST) and the BIST industrial index (IND).

The study differs from the previous studies in terms of adding the "geopolitical risk index" for Turkey (GPR) and the "economic policy uncertainty index" of the United States of America (EPU) to the equation next to the already known macroeconomic variables in order to investigate the causal relationship between macro variables and stock returns in Turkey. In order to represent the effect of "economic policy uncertainty" to the Turkish stock returns, the study benefited from the Economic Policy Uncertainty index of the United States of America (EPU). The study uses the EPU of the USA, since; first of all, there is no economic policy uncertainty index developed or calculated for Turkey yet. Secondly, the global economic policy uncertainty index (GEPU) could have been used for the study in place of the EPU, but the GEPU data series starts from the beginning of 1997 not from 1991. Thirdly, the examination of the data series' of EPU and GEPU after the period of 1997 shows that the two data series are correlated and the EPU data represents the developments of GEPU data also. Finally, the use of EPU is important since the study aims to see the effect of external monetary policy shocks on Turkish stock returns.

The industrial production index (IPI) of Turkey is used in the study to see the effect of economic activity to stock returns. On theoretical grounds, a positive relationship between stock prices and industrial production index is expected since increase in output may boost cash flow and hence, enhance the stock prices. Empirical studies from Chen et al. (1986), Fama (1990), Schwert (1990), Mahdavi and Sohrabian (1991), Abdullah and Hayworth (1993), Gallinger (1994), Apergis (1998) and Tiryaki et al. (2017), among others, support this positive relationship.

The real effective exchange rate is another variable that is also included in the study. Theoretically, the sign of the relationship between the RER and the stock returns could be negative or positive. There could be a negative relationship between stock prices and the home currency; if exports are important for a country, the real exchange rate appreciation lowers the country's competitiveness and negatively affects domestic stock prices/returns. Choi (1995) notes that the exchange rate is the most significant factor among the macroeconomic variables that affects the stock returns.

Stock prices/returns are also affected from the changes in the price level. Theoretically, the expected sign of the relationship could be negative or positive. According to the Classical theory, such relationship is induced by the negative inflation-real activity relationship, as Fama (1981) 
suggests. The Keynesian approach claims that there is positive relationship between economic activity and price level and hence there should be a positive relationship between economic activity and the stock returns. The empirical study results are also controversial and do not solve the theoretical argument about the sign of the relationship. The negative stock return-inflation relationship is empirically reported by Fama (1981), Schwert (1981), Gultekin (1983), Geske and Roll (1983) and Mukherjee and Naka (1995). However, Abdullah and Hayworth (1993) found a positive relationship.

Changes in interest rates affect the cost of borrowing and also effects future profitability of the firms. Decreases in interest rates reduces the cost of borrowing for firms and encourages them for expansion with the expectation of generating future expected returns for the firm. Also, the interest rate changes play an important role in stock price movements.

The uncertainties in economic policy can be defined as the uncertainty in the decisions of economic policymakers, which impact the decisions of economic units on the issues related to consumption, investment, saving, lending, etc. Theoretically, a negative or positive relationship is expected between the increases in the Economic Policy Uncertainty index of the United States of America (EPU) and stock returns. According to Li et al. (2016), if EPU does have significant impacts on these economic fundamentals then it would also be expected to have real impacts on stock market performance. The negative relationship arises because the uncertainty about economic policies that fuels market participants' pessimistic considerations about expected future dividends and/or discounts rates probably leads to a decline in stock prices (Chan et al. (2017)). According to the this theory, the investors are uncertain about the timing, content, and potential impact of policy decisions. Thus, the adjustment of investors' expectations when a new surprise information arrive will influence the stock prices. Hence, economic policy uncertainty influences investors' expectations about potential policy effect on stock prices. Chan et al. (2017), suggest that the economic policy uncertainty increases the cost of raising equity capital for firms, especially when the economy is weak. Brogaard and Detzel (2015) on the other hand suggest that the EPU may have a positive effect on stock prices if economic policy-induced uncertainty would increase equity risk premium and hence lead to a higher stock price.

Increases in economic policy uncertainty in large economies could have positive or negative spillover effects in emerging economies through an increase or decrease in capital inflows. A positive effect could occur if the investors in large economies, such as the US, shift more of their investment abroad given the declined attractiveness of investing in the US or in the EU since increased policy uncertainty would tend to hinder domestic growth prospects. The effect could be negative on emerging economies, in case a higher policy uncertainty in large economies may decrease investors' willingness to take risks and therefore lead to a decrease in the overall size of their allocations to emerging markets in order to stay safe at home.

In this study, the ARDL methodology is used for estimations. The ARDL estimation results show that main determinants of Turkish stock returns in the long run are the changes in IPI, RER and CPI positively and the EPU negatively. Turkey's Geopolitical risk index (GPR) has found no impact on Turkish stock returns in the long run.

This paper is organized as follows: The literature survey includes both the surveys of International and Turkish stock market theoretical and empirical studies. Then the econometric methodology and data is discussed. Empirical findings and policy implications finalize the paper.

\section{Theory and Literature Review}

Macroeconomic variables have a significant impact on stock market performance and reversely. Many studies have reported the effects of the changes in macroeconomic variables on stock prices in different countries. The Classical and Keynesian theories imply a positive relationship between growth in economic activity and the stock market returns. Increase in economic activity increases the current and future profitability of the firms and hence increases 
the stock prices. Theoretical studies from Chen et al. (1986), Fama (1990), Abdullah and Hayworth (1993), Gallinger (1994), and Mukherjee and Naka (1995) showed that stock returns are positively related to real economic activity. Empirical country specific studies from Gjerde and Sættem (1999), Kwon and Shin (1999), Nasseh and Strauss (2000), Ratanapakorn and Sharma (2007), Vazakidis and Adamopoulos, (2009), Acikalin et al. (2008), Shahbaz, et al. (2008), Humpe and Macmillan (2009), Yartey (2010), Singh, et al. (2011), Kumar and Padhi (2012), Pradhan et al. (2013), Şükrüoğlu and Nalin (2014) and Tiryaki et al. (2017) found the same positive relationship.

However, Levine and Zervos (1998) found reverse causation suggesting that the stock market development has positive impact on long-run economic growth. Interestingly, Naceur et al. (2007) and Sahu and Dhiman (2011) investigated the causal relationship and the direction of causality between stock market development and economic growth and found no causal relationship.

Theoretically, change in exchange rate affects the global performances of the firms which will affect their share prices. According to Abdalla and Murinde, (1997), the volatility of the exchange rate is greater under the flexible exchange rate system and leads to exchange rate risks. Theoretically, there exist a negative relationship between stock prices and the home currency. For example, if exports are important for a country, the exchange rate appreciation lowers its competitiveness and negatively affects domestic stock prices. Ratanapakorn and Sharma (2007), by investigating the relationships between the US stock price index and macroeconomic variables, found that the stock prices are positively related to the exchange rate. In contrast, Singh et al. (2011), for Taiwan, showed that the changes in exchange rate have a negative effect on returns for portfolios of big and medium companies. On the other hand, Aydemir and Demirhan (2009), for Turkey, and Tripathy (2011), for the India, presented evidence of bi-directional relationship between exchange rate and stock market.

As the economic theory suggest that the relationship between the inflation and the stock market returns can be positive or negative. According to the classical theory and to Fama (1981), such negative relations are induced by the negative inflation-real activity relationship and so, stock returns are positively related to real variables like investment expenditures and output, but negatively related to the inflation. The positive relationship, on the other side, is indicated by the Keynesian approach since there is positive relationship exist between macroeconomic activity and price level and hence there should be a positive relationship between activity and the stock returns. Naceur et al. (2007) and Ratanapakorn and Sharma (2007) found that the stock prices are positively related to inflation. However, Humpe and Macmillan (2009), for the USA and Japan, Kumar and Padhi (2012), for the Indian stock market, Şükrüoğlu and Nalin (2014), for selected 19 European countries, found that the stock returns are negatively related to the inflation. Singh et al. (2011) for Taiwan, show that inflation has a negative effect on returns for portfolios of big and medium companies. Pradhan et al. (2013), for 16 Asian countries, found the existence of bidirectional causal relationship between stock market development and inflation.

Changes in interest rates affect the cost of borrowing and effects future profitability of the firms. For example, an increase in interest rates rises the cost of borrowing and discourages firms for expansion with the expectation of reduced future expected returns for the firm. Interest rate changes play an important role in stock price movements. Empirical studies by Ratanapakorn and Sharma (2007) and Humpe and Macmillan (2009) found that the stock prices are negatively related to the long-term interest rate, but positively related to the short-term interest rate. However, Tripathy (2011) presents evidence of bi-directional relationship between interest rate and stock market.

Theoretically, a negative relationship is expected between increase in the geopolitical risk and the stock returns of that country. As expected, Berkman et al. (2011) and Carney (2016) suggest that geopolitical risk, together with economic and policy uncertainty, could have significant adverse economic effects and depresses the stock returns. Balcılar et al. (2016) examines the effect in the BRICS stock markets and found that the effect is heterogeneous across the BRICS stock 
markets. GPRs are generally found to impact stock market volatility measures, rather than returns. The empirical results of Caldara and lacoviello (2018) presented evidence that high geopolitical risk leads to a decline in real activity, lower stock returns and movements in capital flows away from emerging economies and towards advanced economies.

Historically there is a discussion whether there is evidence of a strong relationship between stock price changes and unexpected fundamental news information. Roll (1988) suggest that there is little relation between stock prices and news. However, Cutler et al. (1989) links the big-jumps in stock returns and news stories. In line with the aforementioned studies, Niederhoffer (1971) also suggested that the large changes in stock prices are substantially more likely following world events than on randomly selected days.

In this study, it is investigated whether the shocks to EPU of the USA have negative spillover effects on Turkish stock returns. Theoretically, a negative or positive relationship is expected between the increases in the EPU and stock returns. A negative relationship can arise for three reasons; first of all, the uncertainty about economic policies can lead market participants to pessimistic considerations about expected future dividends and/or discounts rates and hence leads to a decline in stock prices. Secondly, the economic policy uncertainty affects stock prices by affecting the investors' expectations. The adjustment of investors' expectations when a new surprise information arrive will influence the stock prices. Finally, the economic policy uncertainty increases the cost of raising equity capital for firms, especially when the economy is weak. On the other hand, a negative spillover effect can arise from the positive shocks to EPU of the USA to Turkish stock returns in case a higher policy uncertainty in the US may decrease investors' willingness to take risks and therefore lead to a decrease in capital inflows to emerging markets, say to Turkey, in order to stay safe at home.

Brogaard and Detzel (2015) suggest that the positive shocks to EPU may have a positive effect on stock prices if economic policy-induced uncertainty would increase equity risk premium. Increases in economic policy uncertainty in the US could also have positive effects on Turkish stock returns if the investors in large economies, such as the US, shift more of their investment abroad given the declined attractiveness of investing in the US or in the EU.

Positive shocks to EPU does have significant impacts primarily on economic fundamentals, then it would also be expected to have real impacts on stock market performance. Previous studies show that this first impact is true. Baker et al. (2016) found that policy uncertainty is associated with greater stock price volatility and reduced investment and employment in policy-sensitive sectors. At the macro level, innovations in policy uncertainty leads to declines in investment, output, and employment in major economies. Jin et al. (2017), by using data from China, reveals that increase in uncertainty significantly raises stock price crash risk and this risk is more pronounced for non-SOEs, small firms and highly profitable firms. Baker et al. (2018) finds that; $40 \%$ US stock price jumps are attributed to policy changes and most of the policy jumps are positive. Fiscal policy jumps are particularly negative for the future stock returns, volatility and GDP growth.

There are various studies that found a negative causal relationship between EPU and the stock returns. Sum (2012a) and Sum (2012b) for the Euro zone, Croatia, Norway, Russia, Switzerland, Turkey, and Ukraine, Bhagat et al. (2013) for India, Antonakakis et al. (2013), Kang and Ratti (2013) for the US, found a negative causal relationship between EPU and the stock returns. The significant negative effect of the EPU on stock returns also finds support from the empirical studies of Boudoukh et al. (2012), Antonakakis et al. (2013), Brogaard and Detzel (2015), Davis (2016), Demir and Ersan (2016), Bayar and Erem Ceylan (2017), Shin et al. (2017) and Baker et al. (2018). However, Brogaard and Detzel (2015) concluded that higher EPU leads to lower contemporaneous stock returns but results in higher future returns. 
Beside the above mentioned studies, the studies from Sum (2012c, 2013) found a negative spillover effects from EPU of the US on the stock market returns in Brazil, India, Russia, and the Association of Southeast Asian Nations (ASEAN) and Han et al. (2016) found the same negative spillovers of EPU from the USA, EU and Japan to China by using a global vector autoregressive (GVAR) model.

There are also studies that found no linkage or no spillover effects between EPU and the stock returns. For China, India, Indonesia, Korea, Malaysia, Pakistan, Philippines, Sri Lanka, Taiwan and Thailand, Donadelli (2015), by using VAR framework, found no statistically significant linkages between changes in the US macroeconomic conditions and Asian stock market excess returns. Li et al. (2016) by applying a bootstrap rolling-window causality test for China and India found bidirectional causal relationships between EPU and stock returns in several sub-periods rather than in the whole sample period. The association between EPU and stock returns is, in general, weak for these two emerging countries. Wu et al. (2016), by applying bootstrap panel Granger causality test for nine countries, indicate that not all countries are alike, and that the theoretical prediction that stock markets fall at the announcement of a policy change is not always supported.

The empirical ARDL test results showed that the Turkish stock returns are positively affected from the changes in LIPI, LRER and LCPI and negatively affected from the changes in the Turkish interest rate (R) and LEPU (negatively) in the short and long-run. Also, the 2008 Global Financial Crisis have negative impact on Turkish stock returns. Interestingly, the geopolitical risk index (GPR) of Turkey does have negative statistically significant impact on only Turkish industrial stock returns in the short run, but not in the long run.

The important and different conclusion of this paper is that increases in economic policy uncertainty (EPU) affect the Turkish stock returns negatively. The results are similar to the results of Sum (2012c, 2013) and Han et al. (2016) showing that there is a negative spillover effect from the positive shocks of EPU of the US to the Turkish stock returns. This study differs from the previous studies related to Turkey in terms of used methodology and the results found. The results are different than the results of Demir and Ersan (2016), since they looked at the effect of EPU on the Borsa Istanbul Tourism Index. It also differs from the results of Bayar and Erem Ceylan (2017), since they checked the impact of macroeconomic uncertainty on Return on Assets (ROA) and Return on Operating Profits (ROAF) by employing panel data analysis within the sample of Borsa Istanbul Non-Metallic Mineral Products sector.

\section{Data and Econometric Methodology}

This study examines the causal relationship between selected macroeconomic variables and the stock returns in Turkey by using monthly data covering the period from 1991:M1 to 2017:M12. The monthly data obtained from the Central Bank of Turkey database ${ }^{3}$, International Financial Statistics (IFS) ${ }^{4}$, Federal Reserve Bank of St. Louis (FRED) ${ }^{5}$, Yahoo finance web database ${ }^{6}$, and the GPR and EPU statistics gathered from the EPU website ${ }^{7}$. The time period is selected for the reason of data availability. The set of macroeconomic variables utilized are the stock market price indexes from Turkey, namely BIST100 index (LBIST) and the BIST industrial index (LIND), industrial production index (IPI), real effective exchange rate (RER), consumer price index (CPI), interest rate $(R)$, Geopolitical risk index for Turkey (GPR) and the Economic Policy Uncertainty index of the United States of America (EPU).

\footnotetext{
${ }^{3}$ https://evds2.tcmb.gov.tr/

${ }^{4}$ http://data.imf.org/?sk=388DFA60-1D26-4ADE-B505-A05A558D9A42

${ }^{5}$ https://fred.stlouisfed.org/

${ }^{6}$ https://finance.yahoo.com/quote/web?ltr=1

${ }^{7} \mathrm{http}: / /$ www.policyuncertainty.com/
} 
In order to represent the behavior of Turkish stock returns the BIST100 index (BIST) and the BIST industrial index (IND) are selected. The BIST financial index is excluded since its behavior resembles the behavior of the BIST 100 index with response to the macroeconomic variables as suggested by Tiryaki et al. (2017).

The study utilized the Autoregressive Distributed Lag (ARDL) method developed by Pesaran and Shin (1999) and re-assessed by Pesaran et al. (2001) to analyze the short-run and long-run linkages between the dependent and independent variables. The approach provides several advantages in evaluation of co-integration and short and long-run linkages. Firstly, unlike the traditional cointegration methods of Johansen's tests (Johansen, 1991), Granger and Engle causality test (Engle and Granger, (1987)) and the Vector Autoregressive (VAR) model, the ARDL can be utilized in order to test for a level relationship for variables that are either $I(0)$ or $I(1)$ as well as for mix $I(0)$ or I(1) variables, as Duasa (2007) and Adom et al. (2012) suggest. However, the ARDL approach does not apply with non-stationary variables integrated of order two $I(2)$. The possibility to combine $I(0)$ or $I(1)$ variables creates huge advantage especially for the test of financial time series since they are often either $I(0)$ or $I(1)$. Also, the use of ARDL method provides more advantages relative to the use of VAR method. The use of the VAR approach requires the series to be stationary. If the data series are non-stationary $I(1)$, one would have to take the first difference of the series and then apply the VAR test. However, as Brooks (2014) suggest, by taking the first difference of the data, the long-run relations between the series may disappear. By contrast, in an ARDL framework, the long-run relationships still remain. Secondly, the ARDL method, by integrating the short-run impact of the given variables with a long-run equilibrium using an error correction term, allows us to assess the short-run and long-run relationship between the given variables simultaneously. Lastly, with the use of ARDL method, it is possible to determine different lags for each variable.

Thus, in order to investigate the causal relationship between selected macroeconomic variables and stock returns, the ARDL approach is used. Following Pesaran and Shin (1999) and Pesaran et al. (2001) and adjusting based equations for our current study aims, the re-arranged ARDL form is defined as follows in equation (1):

$$
\begin{gathered}
\Delta L Y_{t}=\alpha_{0}+\sum_{i=1}^{m_{1}} \sigma_{i t} \Delta L Y_{t-i}+\sum_{i=0}^{m_{2}} \beta_{i t} \Delta L I P I_{i, t-i}+\sum_{i=0}^{m_{3}} \emptyset_{i t} \Delta L R E R_{i, t-i}+ \\
\sum_{i=0}^{m_{4}} \gamma_{i t} \Delta L C P I_{i, t-i}+\sum_{i=0}^{m_{5}} \pi_{i t} \Delta R_{i, t-i}+\sum_{i=0}^{m_{6}} \mu_{i t} \Delta L G P R_{i, t-i}+\sum_{i=0}^{m_{7}} \lambda_{i t} \Delta L E P U_{i, t-i}+\delta_{1 i} L Y_{t-1}+ \\
\delta_{2 i} L I P I_{t-1}+\delta_{3 i} L R E R_{t-1}+\delta_{4 i} L C P I_{t-1}+\delta_{5 i} R_{t-1}+\delta_{6 i} L G P R_{t-1}+\delta_{7 i} L E P U_{t-1}+\varepsilon_{i t}
\end{gathered}
$$

where; $\Delta$ is defined as the first difference of the variables. $L Y$ is defined as the log series of the index of BIST100 (LBIST) or the index of BISTIND (LIND). LIPI is defined as the log series of industrial production index of Turkey. $L R E R$ is defined as the log series of real effective exchange rate of Turkey. $L C P I$ is defined as the log series of consumer price index. $R$ is defined as the Turkish policy interest rate. $L G P R$ is defined as the geopolitical risk index of Turkey and $L E P U$ is defined the economic policy uncertainty index of the USA. $\varepsilon$ is defined as zero mean and constant variance error term.

In order to test for the presence of the long-run relationship between selected macroeconomic variables and the stock returns, Eq. (1) is estimated by ordinary least squares (OLS) and then carried out an F-test for the joint significance of the coefficients of the lagged levels of the variable. Thus, the null and alternative hypotheses of no co-integration among the variables in Eq. (1) is:

$$
\begin{aligned}
& H_{0}: \delta_{1}=\delta_{2}=\delta_{3}=\delta_{4}=\delta_{5}=\delta_{6}=\delta_{7}=0 \\
& H_{1}: \delta_{1} \neq \delta_{2} \neq \delta_{3} \neq \delta_{4} \neq \delta_{5} \neq \delta_{6} \neq \delta_{7} \neq 0
\end{aligned}
$$


By adopting ARDL approach, one can estimate the short and long-run dynamic relationships. Therefore, equation (1) can be rewritten as the error correction version of ARDL model as follows in equations (4) and (5):

$$
\begin{aligned}
& \quad L Y_{t}=\alpha_{0}+\sum_{i=1}^{s_{1}} \sigma_{i t} L Y_{t-i}+\sum_{i=0}^{s_{2}} \beta_{i t} L I P I_{i, t-i}+\sum_{i=0}^{s_{3}} \emptyset_{i t} L R E R_{i, t-i}+\sum_{i=0}^{s_{4}} \gamma_{i t} L C P I_{i, t-i}+ \\
& \sum_{i=0}^{s_{5}} \pi_{i t} R_{i, t-i}+\sum_{i=0}^{s_{6}} \mu_{i t} L G P R_{i, t-i}+\sum_{i=0}^{s_{7}} \lambda_{i t} L E P U_{i, t-i}+\varepsilon_{i t} \\
& \quad \Delta L Y_{t}=\alpha_{0}+\sum_{i=1}^{n_{1}} \sigma_{i t} \Delta L Y_{t-i}+\sum_{i=0}^{n_{2}} \beta_{i t} \Delta L I P I_{i, t-i}+\sum_{i=0}^{n_{3}} \emptyset_{i t} \Delta L R E R_{i, t-i}+ \\
& \sum_{i=0}^{n_{4}} \gamma_{i t} \Delta L C P I_{i, t-i}+\sum_{i=0}^{n_{5}} \pi_{i t} \Delta R_{i, t-i}+\sum_{i=0}^{n_{6}} \mu_{i t} \Delta L G P R_{i, t-i}+\sum_{i=0}^{n_{7}} \lambda_{i t} \Delta L E P U_{i, t-i}+\delta_{1 i} L Y_{t-1}+ \\
& \delta_{2 i} L I P I_{t-1}+\delta_{3 i} L R E R_{t-1}+\delta_{4 i} L C P I_{t-1}+\delta_{5 i} R_{t-1}+\delta_{6 i} L G P R_{t-1}+\delta_{7 i} L E P U_{t-1}+\delta_{8 i} E C T_{t-1}+ \\
& \varepsilon_{i t}
\end{aligned}
$$

where $E C T_{t-1}$ in equation (5) is the error correction term whose coefficient has to be negative and statistically significant and represents the speed of adjustment revert to long run equilibrium following a short run shock. After the ARDL tests, the presence of serial correlation and heteroscedasticity in the errors of model are also tested in order to check whether the model is correctly specified the functional form of the model and errors are normally distributed. Additionally, the stability of parameters were checked by using cumulative (CUSUM) and cumulative sum of squares (CUSUMSQ). All test results are reported in the following section.

\section{Empirical Results}

\subsection{The Unit Root Tests}

Table 1 reports the results of the unit root tests in order to determine the order of integration among time series data. The Breakpoint Unit Root test has been used at level and first difference under the assumption of trend and intercept. The results of Breakpoint unit root test indicates that variables of LCPI, R, LGPR and LEPU are level stationary while other variables of LBIST, LIND, LIPI and LRER are stationary at the first differences. The results provide a strong justification for ARDL as an estimation method to test the existence of long-run relationship among the variables.

Table 1: Breakpoint Unit Root Test Results

\begin{tabular}{cccc}
\hline \multirow{2}{*}{ Variables } & \multicolumn{3}{c}{ Breakpoint Unit Root Test (trend and intercept) } \\
& Level & 1st difference & Decision \\
\hline \multirow{2}{*}{ LBIST } & $-3.5297^{*}$ & $-9.3949^{*}$ & \\
LIND & $(-5.1550)$ & $(-5.1550)$ & $\mathrm{I}(1)$ \\
& $-3.7714^{*}$ & $-9.3388^{*}$ & $\mathrm{I}(1)$ \\
& $(-5.1550)$ & $(-5.1550)$ & $\mathrm{I}(1)$ \\
LIPI & $-5.0987^{*}$ & $-\mathbf{1 1 . 8 0 1 9 *}$ & \\
& $(-5.1550)$ & $(-5.1550)$ & $\mathrm{I}(1)$ \\
LRER & $-5.1143^{*}$ & $\mathbf{- 1 0 . 2 7 3 3 9 ^ { * }}$ & $\mathrm{I}(0)$ \\
& $(-5.1550)$ & $(-5.1550)$ & $\mathrm{I}(0)$ \\
LCPI & $-4.6337^{*}$ & & $\mathrm{I}(0)$ \\
& $\left(-4.1936^{*}\right)$ & & $\mathrm{I}(0)$ \\
R & $-5.6039^{*}$ & & \\
& $(-5.1550)$ & & \\
LGPR & $-9.8427^{*}$ & & \\
& $(-5.1550)$ & & \\
\hline
\end{tabular}

Note: * denotes the rejection of the unit root at $5 \%$ level of significance.

\subsection{The ARDL Bounds Test}

After the determination of the order of the integration of the variables, the presence of longrun relationship between selected macroeconomic variables and the stock returns in BIST100 and BIST industrial index of Turkey is tested by employing the ARDL bounds testing approach. In order 
to test existence of such relationship, first of all optimal lag length by using Akaike information criterion (AIC) is determined. Table 2 reveals the results of the co-integration between dependent variables (LBIST and LIND) and the independent macroeconomic variables (LIPI, LRER, LCPI, R, LGPR and LEPU) and also the critical values of ARDL bounds test.

Table 2: The ARDL Bounds Test

\begin{tabular}{lccccc}
\hline $\begin{array}{l}\text { Model: } \\
\text { LBIST or LIND = f(IPI, } \\
\text { RER, CPI, R, GPR, EPU) }\end{array}$ & Optimal lag length & F-statistics & $\begin{array}{c}\text { Bound critical } \\
\text { value }\end{array}$ & Outcome \\
\hline & & & $\mathrm{I}(0)$ & $\mathrm{I}(1)$ & \\
LBIST & $(11,0,6,6,3,0,8)$ & $\mathbf{3 . 9 7 6 8 5 3 ^ { * }}$ & 2.27 & 3.28 & Cointegration \\
LIND & $(7,6,2,1,5,1,0)$ & $\mathbf{4 . 1 2 4 1 1 6 *}$ & 2.27 & 3.28 & Cointegration \\
\hline
\end{tabular}

Note-1: ${ }^{*}$ denotes the rejection of the unit root at $5 \%$ level of significance.

Note-2: Bounds critical values are taken from Pesaran et al. (2001) with restricted intercept and no trend.

The results in Table 2 indicate that the calculated F-statistics reject the null hypothesis of no co-integration among variables, since calculated values of F-statistics for LBIST and LIND (3.976 and 4.124 respectively) are greater than I(1) bound critical value of 3.28 at the significance level of $5 \%$. Thus, the variables are co-integrated which implies that there is a long-run relationship among them. The short-run parameters are obtained by estimating an error correction model associated with the long-run estimates. Tables 3 and 4 reveal the results of short-run and long-run estimates.

Table 3 shows the short and long-run relations between Turkey's BIST100 index (LBIST) and the independent variables of LIPI, LRER, LCPI, R, LGPR and LEPU. The test also includes the dummies representing the 2001 and 2008 financial crisis effects that created structural breaks on the data. The ARDL estimation results reveal that in the short-run the LBIST stock returns are positively determined by the changes in LIPI, LRER, LCPI and negatively determined by the changes in the R, LEPU and the dummy representing the impact of the 2008 Global Financial Crisis. The long-run determinants of the BIST100 stock returns are the changes in LIPI, LRER, LCPI and the LEPU. The changes in LIPI, LRER, and LCPI have positive significant impact, but the changes in the LEPU has negative impact on stock returns. The $R$ and LGPR have found no impact on Turkish BIST100 stock returns in the long-run.

For the short-run, the estimated coefficient of LIPI, LRER and LCPI are statistically significant and have a positive sign. But, the estimated coefficient of R, LEPU with a lag and the dummy representing the impact of the 2008 Global Financial Crisis are statistically significant and have a negative sign. In the long-run, the estimated coefficient of LIPI, LRER, and LCPI are statistically significant and positive. But, the estimated coefficient of the LEPU is statistically significant and negative.

The negative and statistically significant estimate of the CointEq(-1) coefficient, $(-0.235619)$, which is another way of representing $E C T_{t-1}$, provides another evidence for established long-run relationship between selected macroeconomic variables and the LBIST stock returns of Turkey. According to estimated value of speed of adjustment coefficient, changes in LBIST are corrected by $24 \%$ in each month. In order to check the robustness of the model, as it can be seen at the bottom of the Table 3, the presence of serial correlation and heteroscedasticity in the errors of model are tested by using the Breusch-Pagan-Godfrey Serial Correlation Lagrange Multiplier (LM) test and White heteroscedasticity test are used respectively. Also, normality test and Ramsey reset test are used to see whether the errors are normally distributed and the model is correctly specified the functional form of the model. The $p$-values of chi-square tests results imply that; the model is well specified, the errors are normally distributed, there is no serial correlation and there is no heteroscedasticity problem. 
Table 3: Long-Run and Short-Run Estimations of LBIST (BIST100)

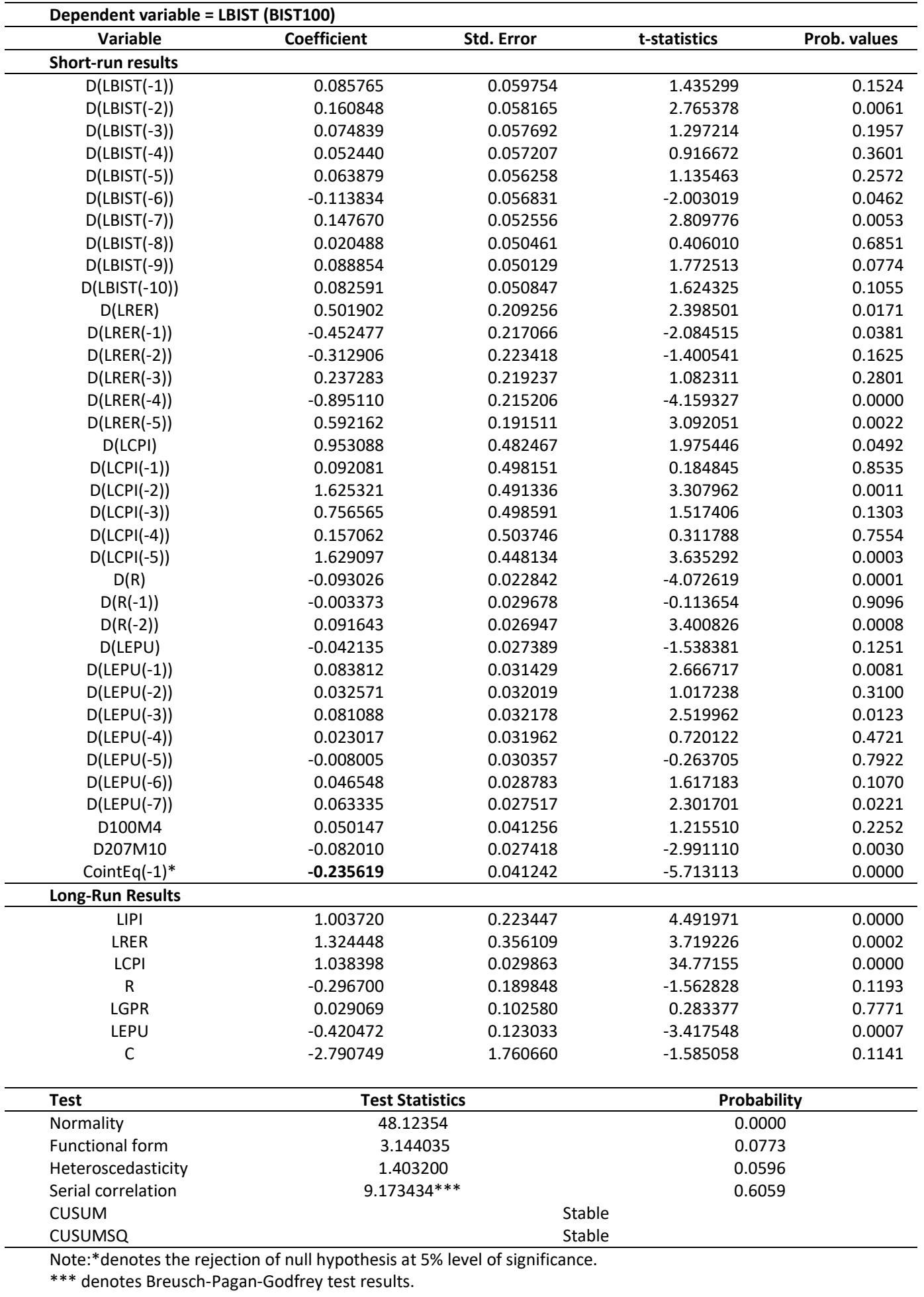

Table 4 shows the short and long-run relations between Turkey's BIST Industrial index (LIND) and the selected macroeconomic variables. The test also includes the dummies for the 2001 and 2008 financial crisis. The ARDL estimation results show that the short-run determinants of the BIST Industrial stock returns (LIND) are the changes in IPI with a lag and difference of IPI with a lag, LRER 
and LCPI and the Turkish interest rate (R) and its one lag, LEPU, Geopolitical risk index (LGPR) for Turkey and the dummy representing the impact of the 2008 Global Financial Crisis. The effect is positive for the changes in IPI, RER and CPI. The negative effect is found for the changes in R, EPU, GPR and dump variable representing the 2008 crisis. In the long-run, the positive determinants of the BIST Industrial stock returns are the changes in LIPI and LCPI and the negative determinant of the returns is only the changes in LEPU. Turkey's interest rate (R) and Geopolitical risk index (LGPR) have no impact on Turkish BIST Industrial stock returns in the long run.

In the short-run, the estimated coefficient of IPI and difference of IPI with a lag, LRER and LCPI are statistically significant and have positive impact on LIND. But, the estimated coefficient of $R$ and its one lag, LEPU, LGPR and the dummy variable representing the impact of the 2008 Global Financial Crisis are statistically significant and have a negative impact on LIND. In the long-run, the estimated coefficient of LIPI and LCPI are statistically significant and have positive impact on LIND. But, the estimated coefficient of LEPU is statistically significant and has a negative sign.

Table 4:Long-Run and Short-Run Estimations of LIND (BIST INDUSTRIAL)

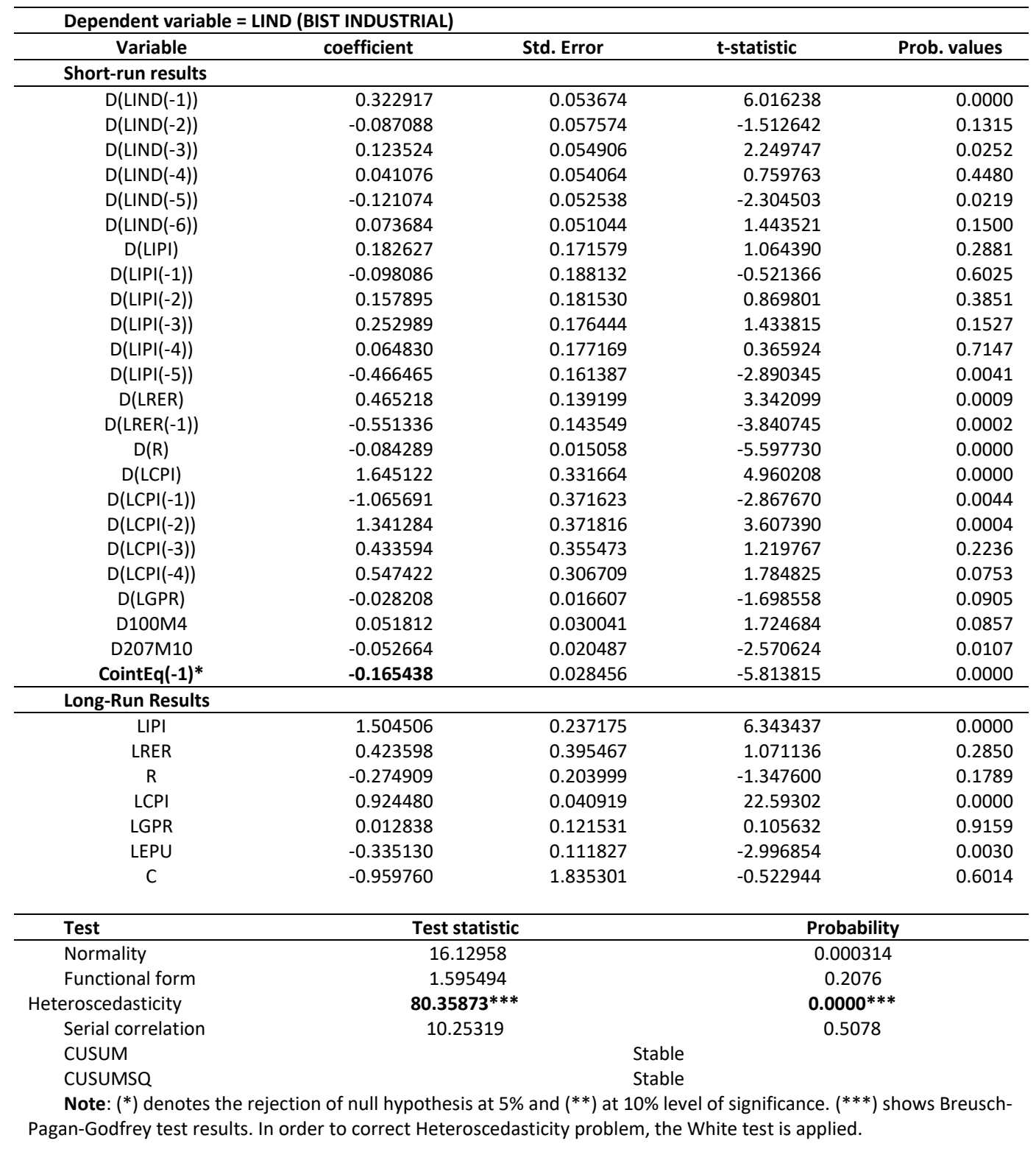


The estimate of the CointEq(-1) coefficient, $(-0.165438)$, has a negative sign and it is statistically significant, which provides another evidence for established long run relationship between selected macroeconomic variables and the LIND stock returns. The estimated value of CointEq(-1) coefficient indicates that changes in LIND are corrected by $17 \%$ in each month.

As it can be seen from the bottom part of Table 4, according to the p-values of chi-square tests results; the model is well specified, the errors are normally distributed, there is no serial correlation and there is no heteroscedasticity problem. As it can be noticed from the bottom of table 4, the test statistic and probability values for heteroscedasticity indicate the existence of heteroscedasticity problem for the model. However, in order to correct the Heteroscedasticity problem, the White test is applied and heteroscedasticity consistent White standard errors are used and reported accordingly.

\section{Conclusion}

This paper investigates the short and long-run macroeconomic determinants of the Turkish stock returns under the impact of the "GPR of Turkey and global economic policy uncertainty" by using the ARDL method. The results of the model show that the short and long-run determinants of the Turkish stock returns are the changes in LIPI, LRER and LCPI, R and LEPU. The effect of the changes in LIPI, LRER and LCPI are positive and the effect from the changes in R and LEPU are negative on the Turkish stock returns. Beside the macroeconomic variables, the 2008 Global Financial Crisis also have negative impact on Turkish stock returns. These significant effects are expected and are in line with the theoretical and empirical studies.

The positive relationship between IPI and stock returns implies that increase in economic activity causes stock prices and hence returns to increase. The test results also show positive relationship between RER and the stock returns in the long run. Since Turkey has an intermediate and final goods depended economy, overvaluation of lira makes imports cheaper and reduces input costs in production. As a result, as suggested by Özer (2015), overvaluation of lira causes firms' future profitability. The positive relationship between inflation and stock returns confirms the expectations of the Keynesian approach. The negative effect of the interest rate is expected and shows that increase in interest rate causes the cost of borrowing to increase and hence reduces the current and future profitability of firms.

The important conclusion of this paper is that increases in economic policy uncertainty (EPU) negatively affect the Turkish stock returns. This result shows the external demand and supply shocks' have effects on the domestic stock market. As the theory suggest, increases in economic policy uncertainty in the USA could have negative spillover effects in emerging economies through a decrease in capital inflows since a higher EPU of the US may decrease investors' willingness to take risks and therefore lead to a decrease in the overall size of capital flows to emerging markets in order to stay safe at home. Thus, the existence of trade and financial capital dependencies of the economy may enhance this negative effects and reducing these effects may require policies in order to reduce economic dependency and this requires long time periods.

Based on the empirical test results, the investors of Turkish stock markets should pay attention to both the domestic and international macroeconomic developments, depending on the short and long-run developments in these selected variables.

\section{References}

Abdullah, D.A. and Hayworth, S.C., (1993). Macroeconomics of Stock Price Fluctuations. Quarterly Journal of Business and Economics, 32, 50-67.

Abdalla, A. and Murinde, V., (1997). Exchange Rate and Stock Price Interactions in Emerging Financial Markets: Evidence on India, Korea, Pakistan and the Philippines. Applied Financial Economics, 7(1), 25-35. 
Acikalin, S., Aktas, R., and Unal, S., (2008). Relationships between Stock Markets and Macroeconomic Variables: An Empirical Analysis of the Istanbul Stock Exchange. Investment Management and Financial Innovations, 5(1), 8-16.

Adom, P.K., Bekoe, W. and Akoena, S.K.K., (2012). Modelling Aggregate Domestic Electricity Demand in Ghana: An Autoregressive Distributed Lag Bounds Cointegration Approach. Energy Policy, 42, 530-537.

Antonakakis, N., Chatziantoniou, I., and Filis, G., (2013). Dynamic Co-movements of Stock Market Returns, Implied Volatility and Policy Uncertainty. Economic Letters, 120(1), 87-92.

Apergis, N.T. (1998). Stock Market Volatility and Deviations from Macroeconomic Fundamentals: Evidence From GARCH And GARCH-X Models. Kredit und Kapital, Heft 3, 400-412.

Aydemir, O. and Demirhan, E. (2009). The Relationship Between Stock Prices and Exchange Rates: Evidence From Turkey. International Research Journal of Finance and Economics, 23, 207215.

Baker, S., Bloom N., and Davis, S.J., (2016). Measuring Economic Policy Uncertainty. Quarterly Journal of Economics, 131(4), 1593-1636.

Baker, S., Bloom, N., Davis, S.J., and Sammon, M., (2018). What Triggers Stock Market Jumps?. Work in progress, presented at Jan. 7th, 2018. Chicagobooth.

Balcilar, M., Bonato, M., Demirer, R. and Gupta, R., (2016). Geopolitical Risks and Stock Market Dynamics of the BRICS. Economic Systems, DOI: 10.1016/j.ecosys.2017.05.008.

Bayar, Y. and Erem Ceylan, I ., (2017). Impact of Macroeconomic Uncertainty on Firm Profitability: A Case of BIST Nonmetallic Mineral Products Sector. Journal of Business Economics and Finance, 6(4), 318-327.

Berkman, H., Jacobsen, B., and Lee, J.B., (2011). Time-varying Rare Disaster Risk and Stock Returns. Journal of Financial Economics, 101(2), 313-332.

Bhagat, S., Ghosh, P., and Rangan, S.P., (2013). Economic Policy Uncertainty and Economic Growth in India, Research Paper No. 407. Indian Institute of Management (IIM), Bangalore, India.

Boudoukh, J., Feldman, R., Kogan, S., and Richardson, M., (2012). Which News Moves Stock Prices? A Textual Analysis. NBER Working Paper No. 18725.

Brogaard, J. and Detzel, A., (2015). The Asset-Pricing Implications of Government Economic Policy Uncertainty. Management Science, 61, 3-18.

Brooks, C. (2014). Introductory Econometrics for Finance. Cambridge University Press, 3rd Edition.

Caldara, D. and lacoviello, M., (2018). Measuring Geopolitical Risk. FRB International Finance Discussion Paper No. 1222. Available at SSRN.

Carney, M., (2016). Uncertainty, the Economy and Policy. Bank of England.

Chan, Y-C and Saffar, W. and Wei, John,K.C., (2017). How Economic Policy Uncertainty Affects the Cost of Raising Equity Capital: Evidence from Seasoned Equity Offerings. Available at SSRN: https://ssrn.com/abstract=3017843.

Chen, N.-F., Roll, R. and Ross, S. A., (1986). Economics Forces and the Stock Market. Journal of Business, 59(3), 383-403.

Choi, J.J. (1995). The Japanese And US Stock Prices: A Comparative Fundamental Analysis. Japan and the World Economy, 7(3), 347-360

Cutler, D.M., Poterba, J.M. and Summers, L.H., (1989). What Moves Stock Prices?. Journal of Portfolio Management, 15(3), 4-12. 
Davis, S.J. (2016). An Index of Global Economic Policy Uncertainty. NBER Working Paper No. 22740, http://www.nber.org/papers/w22740.

Demir, E., and Ersan, O., (2016). The Impact of Economic Policy Uncertainty on Stock Returns of Turkish Tourism Companies. Current Issues in Tourism, 21(8), 847-855.

Donadelli, M., (2015). Asian Stock Markets, US Economic Policy Uncertainty and US Macro-Shocks, New Zealand Economic Papers, 49(2), 103-133.

Duasa, J. (2007). Determinants of Malaysian Trade Balance: An ARDL Bound Testing Approach. Global Economic Review Perspectives on East Asian Economies and Industries, 36(1), 89102.

Engle, R.F. and Granger, C.W.J., (1987). Co-Integration and Error Correction: Representation, Estimation, and Testing. Econometrica, 55(2), 251-276.

Fama, E.F. (1970). Efficient Capital Markets: A Review of Theory and Empirical Work, Journal of Finance, 25(2), 383-417.

Fama, E.F. (1981). Stock Returns, Real Activity, Inflation, and Money. The American Economic Review, 71(4), 545-565.

Fama, E.F. (1990). Stock Returns, Expected Returns, and Real Activity. The Journal of Finance, 45(4), 1089-108.

Gallinger, G.W., (1994). Causality Tests of the Real Stock Return-Real Activity Hypothesis. Journal of Financial Research, 17(2), 271-288.

Geske, R. and Roll, R. (1983). The Fiscal and Monetary Linkage between Stock Returns and Inflation. The Journal of Finance, 38(1), 1-33

Gjerde, $\varnothing$. and Sættem, F., (1999). Causal Relations among Stock Returns and Macroeconomic Variables in a Small, Open Economy. Journal of International Financial Markets, Institutions and Money, 9(1), 61-74.

Gultekin, N.B. (1983). Stock Market Returns and Inflation: Evidence from Other Countries. The Journal of Finance, 38(1), 49-65

Han, L., Qi, M., and Yin, L., (2016). Macroeconomic Policy Uncertainty Shocks on the Chinese Economy: a GVAR Analysis, Applied Economics, 48(51), 4907-4921.

Humpe, A. and Macmillan, P., (2009). Can Macroeconomic Variables Explain Long-Term Stock Market Movements? A Comparison of the US and Japan. Applied Financial Economics, 19(2), 111-119.

http://data.imf.org/?sk=388DFA60-1D26-4ADE-B505-A05A558D9A42

https://evds2.tcmb.gov.tr/

https://finance.yahoo.com/quote/web?|tr=1

https://fred.stlouisfed.org/

http://www.policyuncertainty.com/

Jin, X., Chen, Z. and Yang, X., (2017). Economic Policy Uncertainty and Stock Price Crash Risk. Available at: sfm.finance.nsysu.edu.tw/php/Papers/.../075-1270825538.p..

Johansen,S. (1991). Estimation and Hypothesis Testing of Cointegration Vectors in Gaussian Vector Autoregressive Models. Econometrica, 59(6), 1551-1580.

Kang, W. and Ratti, R. A., (2013). Oil Shocks, Policy Uncertainty and Stock Market Returns. Journal of International Financial Markets, Institutions and Money, 26, 305-318. 
Kumar, N.P. and Padhi, P., (2012). The Impact of Macroeconomic Fundamentals on Stock Prices Revisited: An Evidence from Indian Data. Munich Personal RePEc Archive MPRA Paper No. 38980, 1-24.

Kwon, C.S. and Shin, T.S., (1999). Cointegration and Causality between Macroeconomic Variables and Stock Market Returns. Global Finance Journal, 10(1), 71-81.

Levine, R. and Zervos S., (1998). Stock Markets, Banks, and Economic Growth. The American Economic Review, 88(3)., 537-558.

Li, X., Balcilar, M., Gupta, R. and Chang, T., (2016). The Causal Relationship between Economic Policy Uncertainty and Stock Returns in China and India: Evidence from a Bootstrap Rolling Window Approach, Emerging Markets Finance and Trade, 52(3), 674-689.

Mahdavi S. and Sohrabian A., (1991). The Link between the Rate of Growth of Stock Prices and the Rate of Growth of GNP in the United States: A Granger Causality Test. The American Economist, 35(2), 41-48.

Mukherjee, T.K. and Naka, A., (1995). Dynamic Relations between Macroeconomic Variables and the Japanese Stock Market: An Application of a Vector Error Correction Model. Journal of Financial Research, 18(2), 223-237.

Naceur, S.B., Ghazouani, S. and Omran, M., (2007). The Determinants of Stock Market Development in the Middle-Eastern and North African Region. Managerial Finance, 33(7), 477-489.

Nasseh, A.and Strauss, J., (2000). Stock Prices and Domestic and International Macroeconomic Activity: A Cointegration Approach. The Quarterly Review of Economics and Finance, 40(2), 229-245.

Niederhoffer, V., (1971). The Analysis of World Events and Stock Prices. The Journal of Business, 44(2), 193-219.

Özer, M. (2015). Can Turkey be a Good Example for the Balkan Nations? The Story of Illusion of Well-Being. In Editon of Xavier Richet, Hasan Hanic and Zoran Grubisic, New Economic Policy Reforms, Belgrade Banking Academy, Belgrade, Serbia, 15-58.

Pesaran, H. and Shin, Y., (1999). An Autoregressive Distributed Lag Modelling Approach to Cointegration Analysis. In S. Strom (eds.) Econometrics and Economic Theory in the $20^{\text {th }}$ Century: The Ragnar Frisch Centennial Symposium Cambridge University Press.

Pesaran, M. H., Shin, Y. and Smith, R. J., (2001). Bounds Testing Approaches to the Analysis of Level Relationships. Journal of Applied Econometrics, 16(3), 289-326.

Pradhan, R. P., Arvin, M. B., Samadhan, B., and Taneja, S., (2013). The Impact of Stock Market Development on Inflation and Economic Growth of 16 Asian Countries: A Panel VAR Approach. Applied Econometrics and International Development, 13(1), 203-220.

Ratanapakorn, O. and Sharma, S. C., (2007). Dynamic Analysis between the US Stock Returns and the Macroeconomic Variables. Applied Financial Economics, 17(5), 369-377.

Roll,R., (1988). R2. Journal of Finance, 43(3), 541-566.

Sahu, N. C. and Dhiman, D. H. (2011). Correlation and Causality between Stock Market and Macro Economic Variables in India: An Empirical Study. International Proceedings of Economics Development and Research, 3, 281-284.

Schwert G. W. (1981). The Adjustment of Stock Prices to Information About Inflation. The Journal of Finance, 36(1), 15-29. 
Schwert G. W. (1990). Stock Returns and Real Activity: A Century of Evidence. The Journal of Finance, $\mathrm{XLV}(4), 1237-1257$.

Shahbaz, M., Ahmed, N. and Ali, L. (2008). Stock Market Development and Economic Growth: ARDL Causality in Pakistan. International Research Journal of Finance and Economics, 14, 182195.

Shin, M., Zhang, B., Zhong, M., and Lee, D.J., (2017). Measuring International Uncertainty: the Case of Korea. Finance and Economics Discussion Series, 2017-066. Washington: Board of Governors of the Federal Reserve System.

Singh, T., Mehta,S. and Varsha, M. S., (2011). Macroeconomic Factors and Stock Returns: Evidence from Taiwan. Journal of Economics and International Finance, 2(4), 217-227.

Sum, V. (2012a). The Impulse Response Functions of Stock Market Returns to Economic Policy Uncertainty, International Review of Applied Financial Issues and Economics (forthcoming). Available at SSRN: https://ssrn.com/abstract=2073184 or http://dx.doi.org/10.2139/ssrn.2073184

Sum, V. (2012b). Economic Policy Uncertainty and Stock Market Performance: Evidence from the European Union, Croatia, Norway, Russia, Switzerland, Turkey and Ukraine, Journal of Money, Investment and Banking, 25, 99-104.

Sum, V. (2012c). The Reaction of Stock Markets in BRIC Countries to Economic Policy Uncertainty in the United States, Working paper series, (available at http://ssrn.com/abstract=2094697).

Sum, V. (2013). The ASEAN Stock Market Performance and Economic Policy Uncertainty in the United States, Economic Papers: A Journal of Applied Economics and Policy, 32(4), 512521.

Şükrüoğlu, D. and Nalin, H.T. (2014). The Macroeconomic Determinants of Stock Market Development in Selected European Countries: Dynamic Panel Data Analysis. International Journal of Economics and Finance, 6(3), 64-71.

Tiryaki, A., Erdogan, L. and Ceylan, R., (2017). The Causal Relationship between Selected Macroeconomic Variables and Stock Returns in Turkey. International Journal of Economics and Administrative Studies, 19, 299-326.

Tripathy, N., (2011). Causal Relationship between Macro Economic Indicators and Stock Market in India. Asian Journal of Finance \& Accounting, 3(1), 208-226.

Vazakidis, A. and Adamopoulos, A. (2009). Stock Market Development and Economic Growth. American Journal of Applied Sciences, 6(11), 1932-1940.

Wu, T-P., Liu, S-B., \& Hsueh, S-J., (2016). The Causal Relationship between Economic Policy Uncertainty and Stock Market: A Panel Data Analysis, International Economic Journal, 30(1), 109-122.

Yartey, A.C. (2010). The Institutional and Macroeconomic Determinants of Stock Market Development in Emerging Economies. Applied Financial Economics, 20(21), 1615-1625. 